\title{
PENGARUH DEBT TO EQUITY RATIO, NET PROFIT MARGIN, RETURN ON EQUITY, QUICK RATIO TERHADAP EARNING PER SHARE PERUSAHAAN SUB SEKTOR TEKSTIL DAN GARMEN YANG TERDAFTAR PADA BURSA EFEK INDONESIA TAHUN 2014-2017
}

\author{
Moniq Aditya Dhira Yanutama \\ adityamoniq@gmail.com \\ Universitas Ahmad Dahlan \\ Deny Ismanto \\ denoxis@yahoo.com \\ Universitas Ahmad Dahlan
}

\begin{abstract}
ABSTRAK
This research was conducted with the aim of empirically testing the effect of Debt To Equity Ratio, Net Profit Margin, Return On Equity, Quick Ratio Against Earning Per Share for Companies in the Textile and Garment Sub Sector Listed on the Indonesia Stock Exchange for the 2014-2017 Period. The research period was carried out for 4 (four) years, namely 2014-2017. This type of research is causal research, that is, this study looks for a causal relationship between independent variables and the dependent variable. The population in this study were all textile and garment sub-sector companies listed on the IDX, which were 18 textile and garment sub-sector companies. The sample in this study was obtained by purposive sampling method. Based on existing criteria, 14 textile and garment sub-sector companies were obtained. Hypothesis testing is done by multiple linear regression analysis. The results of hypothesis testing are done partially, namely the t test shows that DER has a sig value. $t$ is 0,000 , the regression coefficient (B) is 38,611 and $t$ is calculated: 4,796 , the result states that DER has a significant positive effect on EPS. NPM has a sig value. $t$ is 0,000 , regression coefficient (B) is 12,726 and $t$ is calculated: 29,230 , the result states that NPM has a significant positive effect on EPS. ROE has a sig value. $t$ is 0.002 , the regression coefficient (B) is -1.485 and $t$ is calculated: -3.3321 , the result is that ROE has a significant negative effect on EPS. QR has a sig value. $t$ is 0.480 , the regression coefficient (B) is -13.095 and $t$ is calculated: -0.712 , the result is that $Q R$ has a negative effect that is not significant for EPS.
\end{abstract}

Keywords: Debt to Equity Ratio, Net Profit Margin, Return on Equity, Quick Ratio, Earning Per Share

\section{PENDAHULUAN}

Perkembangan perekonomian yang ada di Indonesia secara tidak langsung menuntut para pelaku usaha untuk berkembang dan bertahan di sektor industrinya. Pasar modal di Indonesia telah menjadi suatu lembaga investasi yang berperan penting dalam meningkatkan pertumbuhan ekonomi dan juga merupakan sarana untuk para perusahaan untuk mendapatkan dana dari investor, dan memperoleh dividen bagi yang memiliki saham. Pasar modal di Indonesia dari tahun ke tahun meningkat sangat pesat yang ditunjukkan dari meningkatnya volume perdagangan, jumlah kapitalisasi pasar dan jumlah emiten dari waktu ke waktu (Djauharotun, 2005). 
Investor memanfaatkan investasi untuk mengembangkan usaha yang dimilikinya, untuk menentukan peluang investasi pada umumnya setiap investor akan lebih memilih investasi pada sahamsaham perusahaan yang memiliki kinerja perusahaan yang baik dan go public, sebab saham yang go public lebih menjanjikan return yang tinggi dengan tingkat resiko yang tinggi. Salah satu sektor yang menjadi incaran para investor adalah sektor aneka industri karena sektor diyakini dapat memimpin sektor-sektor dalam sebuah perekonomian menuju kemajuan dan juga pada saat ini sektor aneka industri telah mengalami perkembangan dan kinerja. Dari semua sub sektor yang ada didalam sektor aneka industri, sub sektor tekstil dan garmen merupakan industri yang akan selalu bertahan, mengingat bahwa industri tekstil dan garmen memenuhi satu di antara kebutuhan dasar manusia, yaitu sandang. Disamping itu sektor tekstil dan garmen sangat penting karena sektor tekstil dan garmen3 Laba Bersih Jumlah Lembar Saham yang Beredar mampu menyerap tenaga kerja lebih banyak dibandingakn dengan sektor lain (Sunardi,2016) turut mempengaruhi harga saham adalah faktor makro ekonomi suatu negara seperti pertumbuhan ekonomi, inflasi, faktor keamanan.

\section{REVIEW LITERATUR DAN HIPOTESIS}

\section{Pasar Modal}

Pasar modal (capital market) adalah pasar keuangan untuk dana-dana jangka panjang dan merupakan pasar yang konkret. Dana jangka panjang adalah dana yang jatuh temponya lebih dari satu tahun. Pasar modal memberikan jasanya yaitu menjembatani hubungan antara pemilik dana dalam hal ini disebut sebagai pemodal (investor) dengan peminjam dana dalam hal inidisebut dengan emiten (perusahaan yang go public).

\section{Investasi}

Investasi adalah penundaan konsumsi sekarang untuk dimasukkan ke aktiva produktif selama periode waktu yang tertentu. Dengan adanya aktiva yang produktif, penundaan konsumsi sekarang untuk diinvestasikan ke aktiva yang produktif tersebut akan meningkatkan utiliti total Jogiyanto (2012). Sedangkan, Menurut Tandelilin (2001), "investasi adalah komitmen atas sejumlah dana atau sumberdaya lainnya yang dilakukan pada saat ini, dengan tujuan memperoleh sejumlah keuntungan di masa yang akan datang".

\section{Earning Per Share (EPS)}

Earning Per Share merupakan jumlah laba yang menjadi hak untuk setiap pemegang satu lembar saham biasa, dan menunjukkan laba bersih perusahaan yang siap dibagikan kepada para pemegang saham. EPS yang tinggi merupakan daya tarik bagi investor. Menurut Tandelilin (2010: 374) Earning Per Share merupakan rasio yang menunjukkan bagian laba untuk setiap saham.

\section{Debt To Equity Ratio (DER)}

Menurut (Kasmir, 2016: 157) adalah Debt to Equity Ratio merupakan rasio yang digunakan untuk menilai utang dengan ekuitas. Rasio ini dicari dengan cara membandingkan antara seluruh utang, termasuk utang lancar dengan seluruh ekuitas.

\section{Net Profit Margin (NPM)}

Menurut (Duci, 2016), Net Profit Margin mengukur sejauh mana kemampuan perusahaan menghasilkan laba bersih dari setiap penjualan. Net Profit Margin yang tinggi menandakan kinerja perusahaan yang semakin produktif dan semakin baik kemampuan perusahaan untuk mendapatkan laba yang tinggi.

\section{Return On Equity (ROE)}

Return On Equity atau rentabilitas modal sendiri merupakan rasio untuk 
mengukur laba bersih sesudah pajak dengan modal sendiri. Rasio ini menunjukkan efisiensi penggunaan modal sendiri. Semakin tinggi rasio ini, semakin baik. Artinya posisi pemilik perusahaan semakin kuat, demikian pula sebaliknya menurut (Kasmir, 2016:201).

\section{Quick Ratio (QR)}

Menurut (Kasmir, 2016: 138) adalah Rasio cepat (Quick Ratio) atau rasio sangat lancar atau acid test rasio merupakan rasio yang menunjukkan kemampuan perusahaan dalam memenuhi atau membayar kewajiban atau utang lancar (utang jangka panjang) dengan aktiva lancar tanpa memperhitungkan nilai sediaan (inventory). Artinya mengabaikan nilai sediaan, dengan cara dikurangi dari total aktiva lancar.

\section{Penelitian Terdahulu}

Dari beberapa hasil penelitian yang relevan mendukung teori yang dikemukakan diatas, maka berikut ini diantaranya yaitu, penelitian dari Sutejo (2009) meneliti: "Analisis Variabel Yang Mempengaruhi Earnings Per Share Pada Industri Food And Baverages Yang Go Public Di Bursa Efek Jakarta". Berdasarkan uraian hasil penelitian dan pembahasan di atas maka dapat ditarik beberapa kesimpulan sebagai berikut: (1) Variabel bebas return on equity(X1), net sales(X2), carrent ratio(X3), debt to equity(X4), inventory turn over (X5), total assets turn over(X6), dan net profit margin $(\mathrm{X} 7)$ secara simultan berpengaruh signifikan terhadap earning per share. (2) Secara parsial net sales(X2) dan carrent ratio(X3) mempunyai pengaruh yang negatif terhadap earning per share. (3) Secara parsial return on equity(X1), debt to equity(X4), total assets turn over(X6), dan net profit margin (X7) ) mempunyai pengaruh yang positif terhadap earning per share (4) Sedangkan inventory turn over (X5) tidak mempunyai pengaruh yang signifikan terhadap eaning per share.
Sihaloho, Priska Katarina meneliti: "Analisis Kemampuan Rasio Keuangan Dalam Memprediksi Laba Per Lembar Saham" .Berdasarkan uraian hasil penelitian dan pembahasan di atas maka dapat ditarik beberapa kesimpulan sebagai berikut: (1) Rasio Economic Profit, memiliki pengaruh positif terhadap laba per lembar saham (2) Financial Profit, memiliki pengaruh positif terhadap laba per lembar saham (3) Net Profit Margin, memiliki pengaruh positif terhadap laba per lembar saham (4) Work Capital to Total Assets, memiliki pengaruh positif terhadap laba per lembar saham (5) Quick Ratio, memiliki pengaruh positif terhadap laba per lembar saham (6) Account Receivable Turnover, memiliki pengaruh positif terhadap laba per lembar saham (7) Cash Flow Operation, memiliki pengaruh positif terhadap laba per lembar saham. Pengaruh yang positif yang artinya rasio tersebut mampu memprediksi laba per lembar saham.

Shinta Kumala, Herry Laksito (2014) meneliti, "Pengaruh Kinerja Keuangan, Ukuran Perusahaan Dan Arus Kas Operasi Terhadap Earnings Per Share." Berdasarkan uraian hasil penelitian dan pembahasan di atas maka dapat ditarik beberapa kesimpulan sebagai berikut: Dari kedelapan faktor yang diteliti (TATO, CR, DER, NPM, ROE, PBV, arus kas operasi dan ukuran perusahaan), terbukti bahwa TATO, DER, NPM, ROE, PBV, arus kas operasi berpengaruh positif terhadap EPS, sedangkan ukuran perusahaan berpengaruh negatif.

\section{Hipotesis}

H1: Debt to Equity Ratio (DER) pengaruh positif terhadap Earning Per Share (EPS).

H2: Net Profit Margin (NPM) pengaruh positif terhadap Earning Per Share (EPS).

H3: Return on Equity (ROE) pengaruh positif terhadap Earning Per Share (EPS). 
H4: Quick Ratio (QR) berpengaruh positif terhadap Earning Per Share (EPS)

\section{METODE PENELITIAN}

\section{Populasi dan Sampel}

Populasi yang digunakan dalam penelitian ini adalah perusahaan sub sektor tekstil dan garmen yang terdaftar di BEI periode 2014-2017, dengan jumlah populasi 18 perusahaan (sahamok). Sampel yang digunakan dalam penelitian ini sebanyak 14 perusahaan. Pengambilan sampel dalam penelitian ini dilakukan dengan menggunakan teknik purposive sampling yaitu pengambilan sampel berdasarkan kriteria tertentu

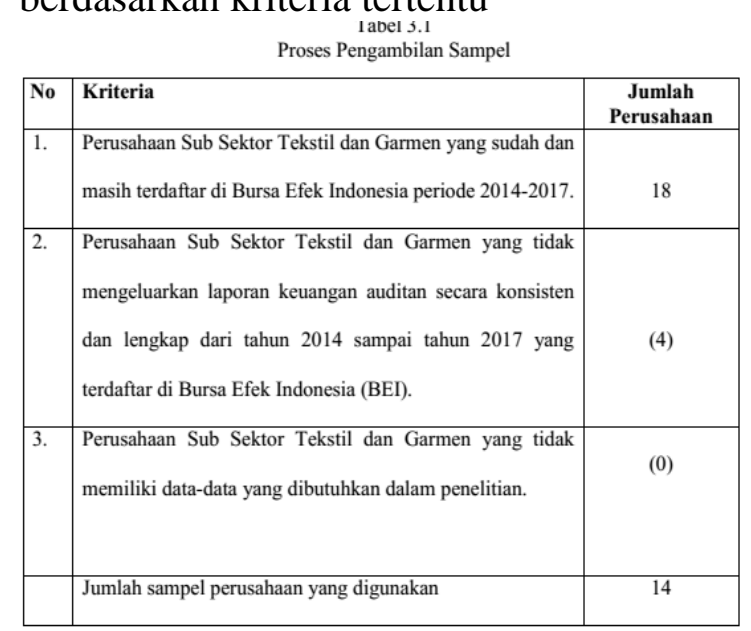

\section{Jenis Sumber Data}

Jenis data penelitian ini adalah sekunder yaitu data penelitian yang diperoleh atau dikumpulkan langsung dari sumber yang telah ada, yaitu data dari perusahaan go publik yang melakukan pengungkapan sosial dalam annual reportnya dan mempublikasikan pada website resmi BEI pada tahun 2014-2017. Dan sumber data sekunder dalam penelitian ini diperoleh dari Laporan Keuangan yang telah diaudit dan dipublikasikan melalui situs resmi Bursa Efek Indonesia (www.idx.co.id).

\section{Teknik Pengumpulan Data}

Data dalam penelitian ini diambil dari laporan keuangan yang diterbitkan di Bursa Efek Indonesia. Metode pengumpulan data menggunakan metode dokumentasi, yaitu suatu metode pengumpulan data yang memperoleh sumber data dari media elektronik, prospektus perusahaan, sampai internet. Dalam hal ini, data laporan keuangan sub sektor perusahaan tekstil dan garmen diperoleh dari laporan keuangan, yang dapat diakses melalui www.idx.co.id. Penelitian ini menggunakan periode penelitian dari tahun 2014-2017.

\section{Definisi Operasional}

\section{Varibel Dependen (Y)}

Earning Per Share merupakan jumlah laba yang menjadi hak untuk setiap pemegang satu lembar saham biasa, dan menunjukkan laba bersih perusahaan yang siap dibagikan kepada para pemegang saham. EPS yang tinggi merupakan daya tarik bagi investor. Menurut Tandelilin (2010: 374) Earning Per Share merupakan rasio yang menunjukkan bagian laba untuk setiap saham. Earning per share (EPS) adalah rasio yang menunjukkan seberapa besar keuntungan (return) yang diperoleh investor atau pemegang saham per saham dengan cara membagi laba bersih setelah pajak dengan jumlah saham biasa yang beredar. EPS dapat dihitung dengan rumus:

$$
\text { EPS }=\overline{\text { Jumlah Lembar Saham yang Beredar }}
$$

\section{Variabel Independen $(\mathbf{X})$}

Variable independent (variable bebas sering disebut variable stimulus, predictor, antecedent. Merupakan variable yang mempengaruhi atau yang menjadi sebab perubahannya atau timbulnya varibel dependen (terikat) (Sugiyono, 2016:64). Variable independent yang digunakan dalam penelitian ini terdiri dari tiga variable diantaranya, yaitu:

\section{a. Debt to Equity Ratio (DER)}

Menurut (Kasmir, 2016: 157) adalah Debt to Equity Ratio merupakan rasio yang digunakan untuk menilai utang 
dengan ekuitas. Rasio ini dicari dengan cara membandingkan antara seluruh utang, termasuk utang lancar dengan seluruh ekuitas. Rasio ini berguna untuk mengetahui jumlah dana yang disediakan peminjam (kreditor) dengan pemilik perusahaan. Dengan kata lain, rasio ini berfungsi untuk mengetahui setiap rupiah modal sendiri yang dijadikan untuk jaminan utang. DER dapat dihitung menggunakan rumus:

$$
D E R=\frac{\text { Total Hutang }}{\text { Total Modal }}
$$

\section{b. Net Profit Margin (NPM)}

Menurut (Duci, 2016), Net Profit Margin mengukur sejauh mana kemampuan perusahaan menghasilkan laba bersih dari setiap penjualan. Net Profit Margin yang tinggi menandakan kinerja perusahaan yang semakin produktif dan semakin baik kemampuan perusahaan untuk mendapatkan laba yang tinggi. Hal ini dikarenakan Net Profit Margin yang tinggi menunjukkan kemampuan perusahaan dalam menyisakan margin yang tinggi atas kompensasi bagi pemilik yang telah menyediakan dananya untuk suatu risiko. NPM dapat dihitung dengan rumus:

$$
N P M=\frac{\text { Laba Setelah Pajak }}{\text { Penjualan }}
$$

\section{c. Return on Equity Ratio (ROE)}

Return On Equity atau rentabilitas modal sendiri merupakan rasio untuk mengukur laba bersih sesudah pajak dengan modal sendiri. Rasio ini menunjukkan efisiensi penggunaan modal sendiri. Semakin tinggi rasio ini, semakin baik. Artinya posisi pemilik perusahaan semakin kuat, demikian pula sebaliknya menurut (Kasmir, 2016: 201). ROE dapat dihitung dengan rumus:

$$
R O E=\frac{\text { Laba Bersih Setelah Pajak }}{\text { Equitas Pemegang Saham }}
$$

\section{d. Quick Ratio $(Q R)$}

Menurut (Kasmir, 2016: 138) adalah Rasio cepat (Quick Ratio) atau rasio sangat lancar atau acid test rasio merupakan rasio yang menunjukkan kemampuan perusahaan dalam memenuhi atau membayar kewajiban atau utang lancar (utang jangka panjang) dengan aktiva lancar tanpa memperhitungkan nilai sediaan (inventory). Artinya mengabaikan nilai sediaan, dengan cara dikurangi dari total aktiva lancar. Quick Ratio dapat dihitung menggunakan rumus:

Quick Ratio $=$ Aktiva Lancar - Persediaan - Persekot Biaya

Kewajiban Lancar

\section{Uji Instrumen}

\section{Statistik Deskriptif}

Statistik deskirptif adalah statistika yang digunakan untuk menganalisis data dengan cara mendeskripsikan data yang telah terkumpul tanpa bermaksud untuk membuat kesimpualan yang berlaku umum. Statistika deskriptif meliputi penyediaan data dalam bentuk tabel-tabel mengenai perhitungan mean, standar deviasi, nialia minimum dan maksimum.

\section{a. Uji Normalitas}

Uji normalitas bertujuan untuk membuktikan bahwa data yang dipergunakan berdistribusi normal. Model regresi yang baik adalah distribusi data normal atau mendekati normal (Thoifah, 2015). Uji normalitas menggunakan uji Jarque-Bera dengan menggunakan bantuan progam statistik. Dasar pengambilan keputusan jika probibalitas lebih besar atau sama dengan nilai alpha yang ditentukan, yaitu 5\%, maka data dikatakan berdistribusi normal, dan sebaliknya jika probibalitas kurang 5\% maka data berdistribusi tidak normal.

\section{b. Uji Autokorelasi}

Menurut Ghazali (2013:110) pengujian asumsi klasik dalam model regresi linier adalah uji autokorelasi bertujuan untuk menguji apakah dalam suatu model regresi linier ada korelasi antara kesalahan penganggu pada periode 
t-1 (sebelumnya). Jika terjadi korelasi maka terdapat problem autokorelasi.

Uji autokorelasi dapat dilihat dari Durbin Waton. Apabila nilai DurbinWaston berada pada daerah dU sampai 4-dU kita dapta menyimpulkan bahwa model regresi tidak mengandung autokorelasi. Denga ketentuan sebagai berikkut:

a. $4-\mathrm{dl}<\mathrm{DW}<4$ mempunyai autokorelasi

b. 4-dU $<$ DW $<4-$ dl tidak ada kesimpulan

c. $\mathrm{dU}<\mathrm{DW}<4-\mathrm{dU}$ tidak ada autokorelasi

d. dL $<$ DW $<$ dU tidak ada kesimpulan

e. $0<\mathrm{DW}<\mathrm{dL}$ mempunyai autokorelasi positif

Uji B-G sering juga disebut sebagai uji LM (Lagrange Multiplier). Uji ini dapat menutupi kelemahan pada uji D-W ketika memberikan hasil "tidak ada kesimpulan". Pengambilan keputusan dapat dilakukan sebagai berikut

Prob. Chi Square > 0,05 tidak ada autokorelasi

Prob. Chi Square $<0,05$ terjadi autokorelasi

\section{c. Uji Heteroskedastisitas}

Pengujian asumsi klasik yang keempat adalah uji heteroskedastisitas (heteriosccdasticity). Pengujian ini bertujuan untuk mengetahui ada tidaknya heteroskedastisitas, dalam hal ini akan dilakukan dengan menggunakan uji statistic, yaitu uji white, Uji ini menggunakan residual kuadrat variabel dependen dan independennya terdiri atas variabel independen yang sudah ada, ditambah dengan kuadrat variabel independen, ditambah dengan perkalian dua variabel independen. Pengambila keputusan dengan menggunakan program Eviews adalah sebagai berikut

Prob. chi square (p-value) $>0,05$ tidak terjadi heteroskedastisitas

Prob. chi square (p- value) $<0,05$ terjadi heteroskedastisitas.

\section{d. Uji Multikolinearitas}

Uji Multikolinearitas merupakan salah satu masalah dalam analisis regresi dengan OLS, yang berarti terdapat korelasi atau hubungan yang sangat tinggi diantara variabel variabel independen.

\section{Teknik Analisis Data}

Teknik analisis data yang digunakan dalam penelitian adalah analisis regresi data panel. Model analisis regresi data panel digunakan untuk mengolah data gabungan yang terdiri dari data silang (cross section) dan data runtut waktu (time series).

\section{Regresi Linier Berganda}

Menurut Sugiyono

(2014:277)

analisis regresi linier berganda bermaksud meramalkan bagaimana keadaan (naik turunnya) variable dependen (kriterium), bila dua variable atau lebih independen sebagai faktor preditaor di manipulasi (dinaik turunkan nilainya). Jadi analisis regresi berganda akan dilakukan bila jumlah variable independennya minimal 2 . Adapun persamaan regresi yaitu sebagai berikut:

$\begin{array}{ll}\text { EPS }=\mathbf{a}+\mathbf{b}_{1} \mathbf{D E R}+\mathbf{b}_{2} \mathbf{N P M}+\mathbf{b}_{3} \mathbf{R O E}+\mathbf{b}_{3} \mathbf{Q R}+\mathbf{e} \\ \text { Keterangan: } & \\ \text { EPS } & =\text { Earning Per Share }(\mathrm{EPS}) \\ \mathbf{a} & =\text { Konstanta } \\ \text { b1, b2, b3 } & =\text { Koefisien regresi dari masing-masing variabel bebas } \\ \text { DER } & =\text { Net Profitt Margin }(\mathrm{NPM}) \\ \text { NPM } & =\text { Return on Equity }(\mathrm{ROE}) \\ \text { ROE } & =\text { Quick Ratio }(\mathrm{QR}) \\ \text { QR } & =\text { Error }\end{array}$

\section{Uji Hipotesis (t-test)}

Uji $t$ pada dasarnya menunjukkan seberapa jauh pengaruh satu variabel penjelas/independen secara individual dalam menerangkan variasi variabel dependen. Pengambilan keputusan penelitian ini diperoleh dengan cara membandingkan t-statistik masing-masing variabel independen dengan t-tabel (one- 
tail) pada tingkat alpha yang ditentukan. Apabila t-statistik lebih besar dari ttabel (one tail) dengan arah yang sesuai maka hipotesis alternatif diterima yang artinya variabel independen tersebut berpengaruh secara signifikan terhadap variabel dependennya, dan begitu pula sebaliknya. Pengujian terhadap hasil regresi dilakukan dengan menggunakan uji $\mathrm{t}$ pada derajat keyakinan sebesar 95\% atau $=5 \%$ Dengan menggunakan besarnya nilai signifikan:

1) Pengujian Hipotesis (H1)

Jika nilai signifikansi uji $\mathrm{t}$ (pada kolom Sig.) < 0,05 maka H0 ditolak dan Ha diterima, artinya Debt To Equity Ratio (DER) berpengaruh terhadap Earning Per Share (EPS) dan sebaliknya jika nilai signifikan > 0,05 maka tidak berpengaruh.

2) Pengujian Hipotesis (H2)

Jika nilai signifikansi uji $t$ (pada kolom Sig.) < 0,05 maka H0 ditolak dan Ha diterima, Net Profitt Margin (NPM) berpengaruh terhadap Earning Per Share (EPS) dan sebaliknya jika nilai signifikan > 0,05 maka tidak berpengaruh.44

3) Pengujian Hipotesis (H3)

Jika nilai signifikansi uji $\mathrm{t}$ (pada kolom Sig.) < 0,05 maka H0 ditolak dan Ha diterima, artinya Return on Equity (ROE) berpengaruh signifikan terhadap Earning Per Share (EPS) dan sebaliknya jika nilai signifikan >0,05 maka tidak berpengaruh.

4) Pengujian Hipotesis (H4)

Jika nilai signifikansi uji $\mathrm{t}$ (pada kolom Sig.) < 0,05 maka H0 ditolak dan Ha diterima, artinya Quick Ratio (QR) berpengaruh signifikan terhadap Earning Per Share (EPS) dan sebaliknya jika nilai signifikan $>0,05$ maka tidak berpengaruh.

\section{Uji Koefisien Determinasi (R2)}

Uji ini digunakan untuk mengukur seberapa jauh kemampuan model regresi dalam menjelaskan variasi variabel dependen (Ghozali, 2011). Nilai koefisien determinasi besarnya antara 0 (nol) dan 1 (satu). Apabila nilai R2 mendekati 0, maka kemampuan variabel independen dalam menjelaskan variabel dependen masih terbatas. Sebaliknya, jika nilai R2 mendekati 1, maka kemampuan variabel independen dalam menjelaskan variabel dependen cukup baik.

\section{HASIL PENELITIAN DAN PEMBAHASAN}

\section{Hasil Penelitian}

\begin{tabular}{|c|c|c|c|c|c|c|}
\hline \multicolumn{7}{|c|}{$\begin{array}{c}\text { Tabel } 4.1 \\
\text { Analisis Deskriptif }\end{array}$} \\
\hline & $\mathrm{N}$ & Minimum & Maximum & Mean & Median & $\begin{array}{c}\text { Std. } \\
\text { Deviation }\end{array}$ \\
\hline EPS & 56 & $-1124,20$ & 2346,41 & $-16,5202$ & 0,08 & 404,05386 \\
\hline DER & 56 & $-7,72$ & 11,10 & 1,0973 & 1,345 & 2,42901 \\
\hline NPM & 56 & $-65,49$ & 184,89 & $-1,9598$ & 0,31 & 29,49381 \\
\hline ROE & 56 & $-253,96$ & 139,77 & $-2,3475$ & 0,46 & 44,10213 \\
\hline$\overline{Q R}$ & 56 & $-0,05$ & 3,27 & 0,6600 & 0,44 & 0,71822 \\
\hline $\begin{array}{l}\text { Valid N } \\
\text { (listwise) }\end{array}$ & 56 & & & & & \\
\hline
\end{tabular}

Sumber: data primer, diolah (2018)

\section{Debt To Equity (DER)}

Hasil uji analisis statistik deskriptif menunjukkan Debt To Equity (DER) (X1) pada perusahaan sub sektor tekstil dan garmen yang terdaftar di BEI periode 2014-2017 dengan nilai terendah yaitu 7,72 , tertinggi yaitu 11,10 , rata-rata (mean) sebesar 1,0973, median 1,345 dan standar deviasi sebesar 2,42901.

\section{Net Profitt Margin (NPM)}

Hasil uji analisis statistik deskriptif menunjukkan Net Profitt Margin (NPM) (X2) pada perusahaan sub sektor tekstil dan garmen yang terdaftar di BEI periode 2014-2017 dengan nilai terendah yaitu 65,49 , tertinggi yaitu 184,89 ratarata (mean) sebesar -1,9598, median 0,31, dan standar deviasi sebesar 29,49381 


\section{Return on Equity (ROE)}

Hasil uji analisis statistik deskriptif menunjukkan Return on Equity (ROE) (X3) pada perusahaan sub sektor tekstil dan garmen yang terdaftar di BEI periode 2014-2017 dengan nilai terendah yaitu 253,96 , tertinggi yaitu 139,77 , rata-rata (mean) sebesar -2,3475, median 0,46, dan standar deviasi sebesar 44,10213.

\section{Quick Ratio $(Q R)$}

Hasil uji analisis statistik deskriptif menunjukkan Quick Ratio (QR) (X4) pada perusahaan sub sektor perkebunan yang terdaftar di BEI periode 2014-2017 dengan nilai terendah yaitu $-0,05$, tertinggi yaitu 3,27 rata-rata (mean) sebesar 0,6600, median 0,44 dan standar deviasi sebesar $0,71822.47$

\section{Earning Per Share (EPS)}

Hasil uji analisis statistik deskriptif menunjukkan Earning Per Share (EPS) (Y) pada perusahaan sub sektor perkebunan yang terdaftar di BEI periode 2014- 2017 dengan nilai terendah yaitu $-1124,20$, tertinggi yaitu 2346,41, rata-rata (mean) sebesar -16,5202, median 0,08 dan standar deviasi sebesar 404,05386.

\section{Uji Normalitas}

Tabel 4.2

Tabel Hasil Uji Normalitas tahap kedua:

One Sample Kolmogorov- Smirnov Test

\begin{tabular}{|l|c|}
\hline & Unstandardiz ed Residual \\
\hline Asymp. Sig. (2-tailed) & 0,250 \\
\hline
\end{tabular}

Berdasarkan hasil uji normalitas menggunakan Kolmogorov-Smirnov tabel 4.2 menunjukkan bahwa residual persamaan regresi pada uji normalitas dengan menggunakan uji KolmogorovSmirnov dapat disimpulkan bahwa persamaan diatas berdistribusi normal, hal ini ditunjukkan pada nilai Asymp. Sig (2tailed) sebesar 0,250, yang mana lebih besar dari $\alpha 5 \%(0,250>0,05)$.

Berdasarkan hasil pengujian kedua dengan melogaritma harga saham dari gambar 4.2 dapat disimpulkan bahwa residual persamaan regresi pada penelitian ini mempunyai distribusi normal. Hal ini terlihat pada nilai Jarque-Bera sebesar 2.66021 dengan nilai Probability 0.263287 yang mana lebih besar dari alpha $5 \%$ (0.05). sehingga dapat disimpulkan penelitian ini berdistribusi normal.

\section{Uji Autokorelasi}

Tabel 4.4

\section{Hasil Uji Durbin -Watson:}

\begin{tabular}{|c|}
\hline Durbin - Watson \\
\hline 2,113 \\
\hline
\end{tabular}

Berdasarkan table 4.4 hasil uji Durbin-Watson adalah 2,113, dengan $n=56$ dan $\mathrm{k}=4$, diperoleh nilai table $\mathrm{D}-\mathrm{W}$, $\mathrm{DL}=1,4201$ dan $\mathrm{DU}=1,7246$. Dengan demikian dapat disimpulkan bahwa DU < D < 4-DU $(1,7246<2,113<2,2754)$ yaitu menunjukkan tidak terjadi autokorelasi.

\section{Uji Heteroskedasitas}

Tabel 4.5

Hasil Uji Glejser:

\begin{tabular}{|l|l|}
\hline Model & Sig. \\
\hline (Constant) & 0,000 \\
\hline DER & 0,631 \\
\hline NPM & 0,241 \\
\hline ROE & 0,285 \\
\hline QR & 0,277 \\
\hline
\end{tabular}

Berdasarkan tabel 4.5 hasil uji Glejser diketahui nilai Sig. variabel DER 0631, Sig. variabel NPM 0,241, Sig. 
variabel ROE 0,285, dan Sig. variabel QR 0,276. Dapat disimpulkan bahwa persamaan diatas tidak terdapat gejala Heteroskedastisitas, hal ini ditunjukkan pada keempat variable nilai Asymp. Sig (2- tailed) $>0,05(\alpha 5 \%)$.

\section{Uji Multikolineiritas}

Tabel 4.3

Berikut ini adalah dari uji Multikolinieritas:

\begin{tabular}{|l|l|l|}
\hline \multirow{2}{*}{ Model } & \multicolumn{2}{|c|}{ Collinearity Statistic } \\
\cline { 2 - 3 } & Tolerance & VIF \\
\hline (Constant) & & \\
\hline DER & 0,408 & 2,450 \\
\hline NPM & 0.946 & 1,057 \\
\hline ROE & 0,401 & 2,493 \\
\hline QR & 0,895 & 1,117 \\
\hline
\end{tabular}

a. Dependent Variabel: EPS

Berdasarkan hasil uji tabel 4.3 diatas diketahui nilai VIF variable DER 2,450, variabel NPM 1,057, variabel ROE 2,493, dan variabel QR 1,117. Karena nilai VIF untuk semua variabel tersebut $<10$ maka dapat disimpulkan persamaan diatas tidak terdapat gejala Multikolinieritas. Dapat juga dilihat dari nilai Tolerance variabel DER 0,408, variabel NPM 0,946, variabel ROE 0,401, dan variabel QR 0,895. Karena nilai Tolerance untuk semua variabel tersebut $>0,01$ maka dapat disimpulkan persamaan diatas tidak terdapat gejala Multikolinieritas.

\section{Regresi Linier Berganda}

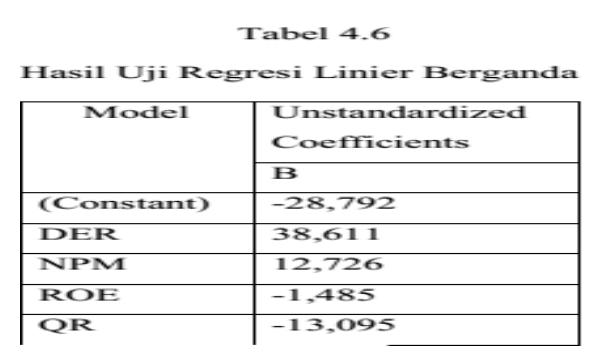

Berdasarkan 4.6 tabel diatas terdapat hasil: $\mathbf{E P S}=\mathbf{a}+\mathbf{b}_{1} \mathrm{DER}+\mathbf{b}_{2} \mathrm{NPM}+\mathbf{b}_{3} \mathrm{ROE}+\mathbf{b}_{3} \mathrm{QR}+\mathbf{e}$

EPS $=-28,792+38,611$ DER $+12,726 \mathrm{NPM}-1,485$ ROE $-13,095 \mathrm{QR}$ a. Konstanta (a)

Nilai konstanta (a) sebesar $-28,792$ menunjukkan bahwa apabila nilai variabel DER,NPM ,ROE, dan QR konstan, maka nilai variabel EPS sebesar - 28,792.

\section{b. Koefisien b1 untuk variabel DER}

Besarnya nilai koefisien regresi (b1) sebesar 38,611 nilai b1 yang positif menunjukkan adanya hubungan yang searah antara variabel EPS dengan variabel DER yang artinya jika nilai variabel DER naik sebesar 1 satuan maka nilai EPS akan naik sebesar 38,611, jika nilai DER turun 1 satuan maka EPS turun sebesar - 38,611. Dengan asumsi variabel bebas lainnya tidak konstan.

\section{c. Koefisien b2 untuk variabel NPM}

Besarnya nilai koefisien regresi (b2) sebesar 12,726 nilai b2 yang positif menunjukkan adanya hubungan yang searah antara variabel EPS dengan variabel NPM yang artinya jika nilai variabel NPM naik sebesar 1 satuan maka nilai EPS akan naik sebesar 12,726, jika nilai NPM turun 1 satuan maka EPS turun sebesar - 12,726. Dengan asumsi variabel bebas lainnya tidak konstan.

\section{d. Koefisien b3 untuk variabel ROE}

Besarnya nilai koefisien regresi (b3) sebesar $-1,485$ nilai b3 yang negatif 
menunjukkan adanya hubungan yang berlawanan arah antara variabel EPS dengan variabel ROE yang artinya jika nilai variabel ROE naik sebesar 1 maka nilai EPS akan turun sebesar -1,485, jika jika nilai variabel ROE turun sebesar 1 maka nilai EPS akan naik sebesar -1,485. Dengan asumsi variabel bebas lainnya tidak konstan.

\section{e) Koefisien b4 untuk variabel QR}

Besarnya nilai koefisien regresi (b4) sebesar -13,095 nilai b4 yang negatif menunjukkan adanya hubungan yang berlawanan arah antara variabel EPS dengan variabel QR yang artinya jika nilai variable QR naik sebesar 1 maka nilai EPS akan turun sebesar -13,095, jika nilai variable $Q R$ turun sebesar 1 maka nilai EPS akan naik sebesar -13,095. Dengan asumsi variabel bebas lainnya tidak konstan.

\section{Uji Parsial (T)}

Tasil uji t:
Tabel 4. I
\begin{tabular}{|l|l|l|l|l|l|}
\hline \multirow{2}{*}{ Model } & \multicolumn{2}{l}{$\begin{array}{l}\text { Unstandardized } \\
\text { Coefficients }\end{array}$} & $\begin{array}{l}\text { Standardized } \\
\text { Coefficients }\end{array}$ & & \multirow{2}{*}{ Sig. } \\
\cline { 2 - 5 } & B & Std. Error & Beta & t & Sial \\
\hline (Constant) & $-28,792$ & 17,878 & & $-1,611$ & 0,113 \\
\hline DER & 38,611 & 8,050 & 0,232 & 4,796 & 0,000 \\
\hline NPM & 12,726 & 0,435 & 0,929 & 29,230 & 0,000 \\
\hline ROE & $-1,485$ & 0,447 & $-0,162$ & $-3,321$ & 0.002 \\
\hline QR & $-13,095$ & 18,385 & $-0,023$ & $-0,712$ & 0,480 \\
\hline
\end{tabular}

Berdasarkan hasil tabel 4.7 hasil uji $\mathrm{t}$ diatas, didapatkan hasil:

a. Nilai sig $t$ DER sebesar 0,000, koefisien regresi (B) sebesar 38,611 dan $\mathrm{t}$ hitung: 4,796, hasilnya menyatakan bahwa DER berpengaruh positif signikan terhadap EPS. Hasil analisis ini menunjukkan bahwa hipotesis pertama yang diujikan dalam penelitian ini yang menyatakan bahwa DER berpengaruh postif signifikan terhadap EPS diterima.

b. Nilai sig t NPM sebesar 0,000, koefisien regresi (B) sebesar 12,726 dan t hitung: 29,230, hasilnya menyatakan bahwa NPM berpengaruh positif signikan terhadap EPS. Hasil analisis ini menunjukkan bahwa hipotesis kedua yang diujikan dalam penelitian ini yang menyatakan bahwa NPM berpengaruh postif signifikan terhadap EPS diterima.

c. Nilai sig $t$ ROE sebesar 0,002, koefisien regresi (B) sebesar -1,485 dan $t$ hitung: -3,321, hasilnya menyatakan bahwa ROE berpengaruh negatif signikan terhadap EPS. Hasil analisis ini menunjukkan bahwa hipotesis ketiga yang diujikan dalam penelitian ini yang menyatakan bahwa ROE berpengaruh postif signifikan terhadap EPS ditolak.

d. Nilai sig $t$ QR sebesar 0,480, koefisien regresi (B) sebesar -13,095 dan $\mathrm{t}$ hitung: -0,712, hasilnya menyatakan bahwa QR berpengaruh negative tidak signikan terhadap EPS. Hasil analisis ini menunjukkan bahwa hipotesis ketiga yang diujikan dalam penelitian ini yang menyatakan bahwa QR berpengaruh postif signifikan terhadap EPS ditolak.

Uji Koefisien Determinasi (R Square)

Tabel 4.8

Hasil Uji R Square:

\begin{tabular}{|l|c|c|}
\hline Model & R & R Square \\
\hline 1 & $0,975^{\mathrm{a}}$ & 0,951 \\
\hline
\end{tabular}

Berdasarkan tabel 4.8 hasil uji $\mathrm{R}$ Square, menunjukkan nilai koefisien determinasi ( R Square ) sebesar 0,951 atau 95,1 \% dari variabel Earning Per Share (EPS) dapat dijelaskan oleh Debt To Equity (DER), Net Profit Margin (NPM), Return on Equity (ROE), dan Quick Ratio 
(QR). Sedangkan sisanya $4,9 \quad \%$ dijelaskan atau dipengaruhi oleh variabelvariabel (faktor atau rasio-rasio keuangan) lain yang tidak di teliti dalam penelitian ini.

\section{Pembahasan \\ Pembuktian Hipotesis 1}

Hipotesis 1 menduga bahwa Debt to Equity Ratio (DER) berpengaruh positif signifikan terhadap Earning Per Share (EPS). Dan hasil penelitian menunjukkan bahwa hipotesis 1 diterima, dimana Debt to Equity Ratio (DER) berpengaruh positif signifikan terhadap Earning Per Share (EPS). Pengaruh yang signifikan menunjukkan bahwa selama ini perusahaan sub sektor tekstil dan garmen mampu memaksimalkan pemenuhan hutang yang dapat ditutupi oleh modal sendiri.

\section{Pembuktian Hipotesis 2}

Hipotesis 2 menduga bahwa Net Profit margin (NPM) berpengaruh positif signifikan terhadap Earning Per Share (EPS). Dan hasil penelitian menunjukkan bahwa hipotesis 2 diterima, dimana $\mathrm{Net}$ Profit margin (NPM) berpengaruh positif signifikan terhadap Earning Per Share (EPS). Pengaruh yang signifikan menunjukkan bahwa selama ini perusahaan sub sektor tekstil dan garmen mampu memaksimalkan laba yang dihasilkan dari perbandingan laba bersih setelah pajak dengan penjualan bersih.

\section{Pembuktian Hipotesis 3}

Hipotesis 3 menduga bahwa Return on Equity (ROE) berpengaruh positif signifikan terhadap Earning Per Share (EPS). Dan hasil penelitian menunjukkan bahwa hipotesis 3 di tolak, dimana Return on Equity (ROE) berpengaruh negatif signifikan terhadap Earning Per Share (EPS). Hasil penelitian ini sama dengan penelitian yang dilakukan oleh, Qoribulloh (2013). yaitu ROE memiliki pengaruh negatif signifikan terhadap Earning Per Share yang berarti bahwa perusahaan tersebut tidak dapat menghasilkan laba dengan modal sendiri yang dapat menguntungkan pemegang saham. ROE yang berpengaruh negatif dapat disebabkan karena tidak semua investor beranggapan bahwa nilai ROE yang tinggi maka kondisi perusahaan bagus tetapi investor melihat nilai ROE yang tinggi terkadang dapat membahayakan kondisi perusahaan. Dikarenakan nilai ROE yang tinggi belum tentu disebabkan perusahaan memperoleh keuntungan yang tinggi, tetapi dapat disebabkan oleh total ekuitas yang dimiliki perusahaan relatif rendah dibandingkan dengan hutang perusahaan. Jika hutang tidak dapat dioptimalkan untuk menambah ekuitas perusahaan dan perusahaan memiliki hutang yang terlalu besar, dapat membahayakan pemilik modal apabila perusahaan tidak mampu membayar kembali hutang dan bunganya. kondisi tersebut yang tidak menarik dan tidak disukai oleh investor.

Dengan demikian selama periode penelitian perusahaan sub sektor tekstil dan garmen tidak mampu memberikan jaminan atas investasi yang dilakukan invertor untuk mendapatkan laba per lembar saham.

\section{Pembuktian Hipotesis 4}

Hipotesis 4 menduga bahwa Quick Ratio (QR) berpengaruh positif terhadap Earning Per Share (EPS). Dan hasil penelitian menunjukkan bahwa hipotesis 4 ditolak, dimana Quick Ratio (QR) berpengaruh negatif terhadap Earning Per Share (EPS). Pengaruh yang negatif menunjukkan bahwa selama ini perusahaan sub sektor tekstil dan garmen belum mampu memaksimalkan melunasi kewajiban jangka pendek atau hutang yang segera jatuh tempo pada saat ditagih secra keseluruhan 


\section{KESIMPULAN DAN SARAN}

\section{Kesimpulan}

Berdasarkan pada hasil penelitian dan pembahasan pada bab sebelumnya, maka dapat disimpulkan berbagai hal sebagai berikut:

1. Debt to Equity Ratio (DER) secara parsial berpengaruh positif signifikan terhadap Earning Per Share (EPS) pada perusahaan sub sektor tekstil dan garmen yang terdaftar di Bursa Efek Indonesia periode 2014-2017.

2. Net Profit Margin (NPM) secara parsial berpengaruh positif signifikan terhadap Earning Per Share (EPS) pada perusahaan sub sektor tekstil dan garmen yang terdaftar di Bursa Efek Indonesia periode 2014-2017.

3. Return On Equity Ratio (ROE) secara parsial berpengaruh negatif signifikan terhadap Earning Per Share (EPS) pada perusahan sub sektor tekstil dan garmen yang terdaftar di Bursa Efek Indonesia periode 2014-2017.

4. Quick Ratio (QR) secara parsial berpengaruh negatif tidak signifikan terhadap Earning Per Share (EPS) pada perusahan sub sektor tekstil dan garmen yang terdaftar di Bursa Efek Indonesia periode 2014-2017..

\section{Saran}

Berdasarkan hasil penelitian yang telah dikemukakan, dapat diberikan beberapa saran sebagai berikut:

1. Bagi Akademisi / ilmu pengetahuan

Bagi akademisi / ilmu pengetahuan disarankan agar hasil penelitian ini dapat dijadikan masukan informasi yang bermanfaat dalam pengembangan penelitian yang lebih baik lagi berhubungan dengan manajemen keuangan.
2. Bagi Investor

Bagi Investor yang ingin menanamkan modalnya (berinvestasi) pada sebuah perusahaan sebaiknya lebih memperhatikan rasio EPS dalam membuat keputusan investasi.

3. Bagi Peneliti Selanjutnya

Bagi peneliti selanjutnya, diharapkan agar menambah variabel independen lainnya yang berhubungan dengan Earning Per Share perusahaan. Mengembangkan penelitian ini dengan model dan metode yang berbeda serta mengganti objek penelitian ini pada industri lainnya dan menambah tahun penelitian agar mendapatkan gambaran yang jelas mengenai tingkat Earning Per Share perusahaan.

\section{DAFTAR PUSTAKA}

Asakdiyah, Salamatun. 2006. Manajemen Keuangan I: Alat Analisis dan Aplikasi. Yogyakarta: Universitas Ahmad Dahlan Yogyakarta.

Bakar, Anwar Abu (Translator). 2012. AlQur'an dan Terjemahannya. Bandung: Sinar Baru Algensindo.

Chantika, Wiena. 2015. Analisis Kinerja Portofolio Saham dengan Metode Sharpe, Treynor, dan Jansen pada Saham LQ 45 di Bursa Efek Indonesia Tahun 2011-2014. Skripsi. Bandung: Universitas Widyatama.

Darmadji, Tjiptono, dan Fakhruddin. 2012: Pasar Modal di Indonesia. Edisi ketiga Jakarta: selemba empat.

Djauharotun. 2005. Pengaruh Earning Per Share Dan Pertumbuhan Penjualan Terhadap Harga Saham Pada Perusahaan Tekstil Dan Garmen Di Bej. Skripsi. Semarang: Universitas Negeri Semarang. 
Duci, Welas. 2016. "Pengaruh Current Ratio, Debt To Equity Ratio, Net Profit Margin Dan Total Asset Turnover Terhadap Earning Per Share (Studi Empiris Pada Perusahaan Publik Sub Sektor Kimia Periode 2011 - 2015)". Jurnal Fakultas Ekonomi.

Ghozali, Imam. 2006. Aplikasi Analisis Multivariat. Semarang: Badan Penerbit Universitas Diponegoro.

Hafiah, M. Ali. 2014. "Pengaruh Current Ratio, Quick Ratio, Inventory Turnover, Total Assets Turnover, Debt to Equity Ratio Terhadap Earning Per Share Pada Perusahaan Industri Barang Konsumsi yang Terdaftar di BEI periode 20092012”. Jurnal Fakultas Ekonomi.

Hanafiah, M. Ali. 2014. "Pengaruh Current Ratio, Quick Ratio, Inventory Turnover, Total Aset Turnover, Debt To Equity Ratio Tehadap Earning Per Share Pada Perusahaan Industri Barang Konsumsi Yang Terdaftar Di Bursa Efek Indonesia Periode 2009 2012".E-

Journal.https://www.Sahamok.com.

Diakses 10 Tanggal 2018. Pada Pukul 19.56 WIB.

https://www.IDX.com. Diakses Tanggal 15 Oktober 2018.Pada Pukul 22.45 WIB.

https://www.sahamok.com/pasarmodal/instrumen-pasar-modal/

Diakses Tanggal 13 Februari 2019. Pada Pukul 22.50 WIB.

https://www.ojk.go.id/sustainablefinance/id/tentang/Pages/PasarModal.aspx Diakses Tanggal 13 Februari 2019. Pada Pukul 23.56 WIB.
Jogiyanto. 2012. Teori Portofolio dan Analisis Investasi: Edisi Ketujuh. Yogyakarta. BPFE - Yogyakarta.

Kasmir. 2016. Analisis Laporan Keuangan. Jakarta: Raja Grafindo Persada.

Prastowo, Dwi. 2011. Analisis Laporan Keuangan. Jakarta. UPP STIM YKPN.

Qoribulloh, A.Rizal. 2013. Pengaruh Rasio Keuangan Terhadap Harga Saham Pada Perusahaan Manufaktur Yang Terdaftar Di Bursa Efek Indonesia Tahun 2011. Skripsi. Yogyakarta: Universitas Negeri Yogyakarta.

Sunardi, Dania Yunitasari. Performance Kinerja Keuangan Pada Sektor Tekstil Dan Garment Yang Terdaftar Di Bei Periode 2010-2014. Skripsi. Semarang: Universitas Dian Nuswantoro.

Sugiyono. 2012. Metode Penelitian Pendidikan Pendekatan Kuantitatif, Kualitatif Dan R\&D. Bandung: Alfabeta.

Sunariyah. 2011. Pengantar Pengetahuan Pasar Modal. Edisi Keenam. Yogyakarta: UPP STIM YKPN.

Tandelilin, Eduardus. 2001, Analisis Investasi dan Manajemen Portofolio Edisi Pertama, Yogyakarta: BPFEYogyakarta

Tandelilin, Eduardus. 2010. Portofolio dan Investasi Teori dan Aplikasi. Edisi pertama. Yogyakarta: Kanisius 